\title{
Cacildas plurais: \\ Uma investigação teatral \\ sobre a presença e a memória
}

JOSÉ DA COSTA

José da Costa é professor da Escola de Teatro e do programa de pós-graduação em Artes Cênicas (PPGAC) da Universidade Federal do Rio de Janeiro (UNIRIO) e investigador no CNPq. Entre vários títulos, é autor de Teatro Contemporâneo no Brasil (2009).

L'article traite de la pièce de théâtre écrite et dirigée par José Celso Martinez Corrêa sur I'actrice consacrée Cacilda Becker. L'interprète, qui est morte en 1969, a été reconnue par ses performances dans le contexte du théâtre moderne brésilien des années 1950 et 1960. En préparant une biographie théâtrale de Cacilda Becker, l'auteur ne se limite pas aux seuls faits objectifs de la vie de l'actrice. II recrée librement beaucoup d'aspects de l'histoire du théâtre et de la culture brésilienne de la période où elle vivait, en discutant aussi le théâtre actuel dans sa double dimension à la fois esthétique et politique. La première du spectacle a eu lieu au siège du Teatro Oficina (Théâtre Atelier) dans la ville de São Paulo, en 1998. La pièce fait partie d'un cycle que l'auteur a créé et mis en scène autour de la vie de l'actrice et de son moment historique.

JOSÉ CELSO MARTINEZ CORRÊA / TEATRO OFICINA / CACILDA BECKER / THÉÂTRE MODERNE BRÉSILIEN / CULTURE BRÉSILIENNE

O final do primeiro dos dois atos da peça-biografia sobre Cacilda Becker - encenada por José Celso Martinez Corrêa em seu Teatro Oficina, com estreia em 1998 - mostra a atriz (preponderantemente interpretada, no primeiro ato, por Bete Coelho e, no segundo, por Leona Cavalli), ainda muito jovem e inexperiente, partindo de Santos, no início da década de 1940, para tentar uma carreira teatral no Rio de Janeiro. Mas, após o intervalo, não vemos o desdobramento da experiência carioca da artista. A chegada ao Rio, o teste para trabalhar junto ao Teatro do Estudante do Brasil, o encontro com a diretora Maria Jacintha, que comandava o grupo na ausência de Pascoal Carlos Magno, e o espetáculo de estréia da atriz são aspectos tematizados em outra peça da tetralogia que José Celso escreveu sobre a vida da atriz Cacilda Becker ${ }^{1}$. 
Após o intervalo entre os dois atos da peça efetivamente encenada, vemos imagens de Cacilda Becker (fotografias e trechos de filmes), além de outras que não parecem ser exclusivamente da atriz e que o espectador tem dificuldade de identificar. Essas imagens são projetadas tanto nos muitos monitores de TV dispostos, em uma parte alta, ao longo do espaço cênico -, quanto em todo o ambiente do teatro - sobre paredes, no chão e mesmo sobre os espectadores. Instantes depois do início das projeções, acompanhamos a entrada em cena da protagonista (agora representada pela atriz Leona Cavalli), que surge na parte superior do teatro, em uma varanda, cuja visibilidade está interceptada aos espectadores por uma cortina branca. A atriz Leona Cavalli aparece diante dessa cortina, que logo será aberta pela intérprete. O que vemos, então, é um coro de atores e atrizes nus. Leona e Zé Celso, que não integram esse coro, parecem, logo depois, fumar ópio ou maconha. Os integrantes nus do coro - que usam máscaras de alumínio que lembram aquelas usadas pelos atores-bailarinos no Bailado do Deus Morto² (1933) de Flávio de Carvalho-, se masturbam todos, homens e mulheres, enquanto cantam, em uníssono, trechos que falam sobre o tempo histórico ( $« 68$ vira 69,/ 69 vira 99»), sexo («todas as coisas que têm boca/ chupam sexos, cacetas e bocetas...»), amor e teatro («Analfabeta/ de viver sem Amor,/ ela se apaixonou/ pela paixão/ da cidade desvairada paulicéia/ coroada pelo/ Trópico das Cabras/ o Teatro.»), etc. As réplicas do coro se alternam com falas de Cacilda em trechos como «oh!, crianças! Criadas! Malcriadas! Oh, meu Trópico das Cabras! Oh Dionizos do meu hemisfério Sul! [...]». A intensidade e a excitação da cena chegam ao auge com o orgasmo dos integrantes do coro. No instante do orgasmo, percebe-se visivelmente a ejaculação de pelo menos alguns dos atores. Cacilda (Leona Cavalli) fala a réplica final em que se refere a «Haxixe/ Estrume/ Bosta/ Mel:/ Céu do chão». Assim finaliza-se o quadro, saindo de cena o coro da masturbação3.

O impacto do episódio se deve ao fato de que não se trata de uma representação indireta de situações em que pessoas 
se masturbam (com atores que fingem ou mimetizam o ato da masturbação), mas da autoexcitação e da masturbação frontal e direta de um conjunto razoavelmente numeroso de atores e atrizes. Mesmo os espectadores mais distantes do local em que ocorre a cena percebem a grande proximidade dos intérpretes em relação à parte do público que se encontra na galeria superior, ao lado da varanda (uma espécie de mezanino) em que se passa a cena. Os espectadores que estão colocados nesse setor da platéia, ainda que não sejam tocados fisicamente pelos integrantes do coro, são, de certa maneira, absorvidos pela cena, não só em decorrência da proximidade efetiva, mas também da iluminação intensamente clara, que não recorta, não reduz, não separa rigidamente o espaço da ocorrência teatral, mas, ao contrário, opta por ampliá-lo e por abri-lo, anexando, de modo indireto, a presença dos espectadores e, em especial, daqueles localizados na área imediatamente contígua.

Os monitores de TV dispostos ao longo do teatro - que, como sabemos, tem a forma de uma pista ou corredor - mostram closes diversos dos indivíduos que se masturbam. Esse recurso faz com que mesmo os receptores mais distanciados no espaço tenham acesso a uma visão extremamente próxima da cena - ou de partes dessa cena e de imagens de fragmentos ampliados (close-up) dos corpos dos atores vistos, com detalhes, em seu dinamismo muscular de autoexcitação. O quadro não mostra os performers tocando-se uns aos outros. A ação de cada um é inteiramente individual. Mas a imagem produzida, simultaneamente grotesca e bela, deve, em grande medida, seu fortíssimo efeito sobre o espectador a essa espécie de situação coletiva de intensidades autoeróticas em operação simultânea e reunida.

Outro momento de grande impacto é a cena que também se dá na mesma varanda ou mezanino do quadro da masturbação. Vemos agora a personagem chamada de Jovem Atriz enquanto ela recebe a aplicação de uma injeção na veia de seu braço. A cena parece bastante realista. Temos a impressão de ver a agulha picar o músculo e penetrar a veia da intérprete. Os monitores ampliam em close a imagem. Até que ponto o receptor complementa ou constitui imaginariamente o que só parcialmente é fornecido pela cena é algo nem sempre suscetível de ser precisamente delimitado, especialmente para quem assiste ao espetáculo uma única vez. Outra atriz também parece ser picada. Alude-se, nas réplicas 
dos atores, à heroína, como se se tratasse de uma cena em que as personagens se drogassem. Mas a palavra heroína é também uma referência à personagem-título da peça, que se constitui simultaneamente como homenagem e como ritual antropofágico, em que se brinda e se devora dionisiacamente a memória da protagonista e do contexto teatral a que pertenceu.

Na cena da aplicação de heroína na personagem Jovem Atriz, há dois planos que se cruzam. Em um deles está a Jovem Atriz que parece vasculhar, anos depois, o amplo apartamento duplex localizado no vigésimo andar de um edifício da avenida Paulista imóvel de que Cacilda Becker foi efetivamente proprietária. A Jovem Atriz parece estar em busca de objetos ou documentos sobre a memória da artista morta no final dos anos 60. De certo modo, a Jovem Atriz representa autorreflexivamente o próprio José Celso em seu ambicioso empreendimento estético-histórico-biográfico, empreendimento esse que foi efetivado com a tetralogia sobre a vida de Cacilda Becker e com a encenação de uma parte da extensa dramaturgia construída.

No outro plano, se encontra a própria estrela de teatro dos anos 50 e 60 dizendo que vai trocar o TBC (Teatro Brasileiro de Comédia) pelo TCB (Teatro Cacilda Becker). A Jovem Atriz, em dado momento, se refere ao TBC dizendo que agora «aquilo lá está uma pastelaria», enquanto o apartamento de Cacilda, onde aparentemente ela se droga, «pelo menos é uma ruína»4. Os dois planos (o da Jovem Atriz no mezanino/apartamento de Cacilda e aquele em que está a estrela ao lado do dramaturgo-encenador José Celso no palco) se intercomunicam, vazam um no outro. O cruzamento e a intercessão dos dois planos se evidencia quando a Jovem Atriz, na varanda superior do teatro (convencionada como o apartamento da avenida Paulista), e a própria Cacilda (Leona Cavalli), no palco-pista-passarela do Oficina, dizem juntas, ainda que em partes separadas do espaço, a seguinte réplica:

$\mathrm{O} \ll \mathrm{C} \gg$ de comédia/ é agora/ «C» de Cacilda./ O «B» de brasileiro/ vira de Becker./ «C»e «B»/ se atraem,/ envolvem/ o «T» do Teatro/ no meio,/ copulam. 
Nesse instante vemos atores (Fransérgio Araújo e Flávio Rocha) que, em um movimento erótico e de grande sensualidade, lembrando quase sátiros míticos, acariciam e beijam os braços das atrizes que foram picadas, lambem o local em que penetrara a agulha enquanto sorriem de êxtase e prazer.

Tanto o episódio do coro da masturbação quanto o da aplicação da heroína parecem se inspirar em parte na viagem que Cacilda Becker fez, em dezembro de 1968, na companhia de Ruth Escobar, a Nova York, onde fora encontrar com Walmor Chagas, que já estava nos Estados Unidos. Nessa viagem, Cacilda experimentou pela primeira vez um cigarro de maconha em Greenwich Village, cheirou poppers e teve contato com o movimento hippie norte-americano que estava em seu ápice. Cacilda também assistiu a trabalhos teatrais que parecem ter tido forte impacto sobre a atriz, a exemplo de Dionysus in 69, do Performance Group de Richard Schechner, espetáculo no qual aspectos como a energia corporal e a nudez dos atores eram fortemente trabalhados (Prado, 2002: 536-540).

É claro que no Brasil havia também uma efervescência cultural que se manifestava, por exemplo, no tropicalismo de nomes como Hélio Oiticia e Caetano Veloso, em atitudes de liberação sexual e comportamental, em espetáculos como O Rei da Vela de Zé Celso e Cemitério de Automóveis, uma produção de Ruth Escobar. Entretanto, vivíamos no país uma radicalização do autoritarismo militar, a partir da edição do Ato Institucional n. ${ }^{\circ} 5$, que ensejou a mais bárbara repressão aos críticos do regime e instaurou um rigoroso sistema de censura aos meios de comunicação e às artes. A idéia de 68 virar 69 tem, de certo modo, relação referencial com o duro contexto de repressão política que Cacilda vai encontrar no país ao voltar da viagem (ao que parece, recheada de alegria e de espontaneidade) à Nova York no mês de dezembro de 1968 e à Europa, onde passou o réveillon. A relação dessas pontuações históricas (68 e 69) com 99 inclui, ao lado da referência dupla à contracultura e à repressão política da ditadura militar, uma referência ao momento em que a peça é encenada no final da década de 90 e em que se volta o olhar para aquele período histórico-cultural do final dos anos 6o, quando se deu a morte de Cacilda Becker, em decorrência de um derrame cerebral ocorrido no intervalo do primeiro para o segundo ato da peça Esperando Godot, com que a atriz estava em cartaz ao lado de Walmor Chagas na cidade de São Paulo. 
Esse arco referencial pode ser confirmado por alguns dados. Por exemplo, pode-se, consultando o texto da peça, ler um trecho que funciona como título do quadro de abertura do segundo ato ou como resumo do episódio, à maneira dos resumos que antecedem cada um dos quadros nas peças de Brecht. Diz a inscrição inicial do segundo ato: «Dia seguinte. O primeiro pós-moderno. New York Grenwich Village. Cacilda Becker Mãe Coragem medita, pita y fuma». Logo depois, há uma rubrica, em que se lê o seguinte:

Títulos brechtianos em slides: Comunidade do teatro de Schechner, em ensaios preparam Dionizos $69^{5}$. Dez atores e atrizes nus passam o cachimbo do hash para Cacilda que pita e viaja numa cena de Mãe Coragem, se masturbando enquanto o coro lê, afastado, a cena. - O coro são os mesmos atores nus que passam o hash, fabricado de barras verdes como pedações de estrume, mas que fazem a cena como atores brechtianos.

O quadro em que há a «viagem» de heroína, quadro intitulado «Mesa Branca \& comunhão Junkie», abre-se com a seguinte rubrica:

Flávio Rangel vem recebê-la. Depois chega Walmor (Chagas). Zimba (Ziembinsky) traz uma grande toalha branca. Se reúnem numa mesa branca, todos se dão as mãos, em torno do palco, na pista. No camarim superior, um camarote da Barca da Glória, onde se localiza o apartamento da atriz na Paulista em 1999. Ruína com grafites junkie na parede: «HOUSE DE CACILDA》, uma TV velha, mal sintonizada, ligada aleatoriamente. A Jovem Atriz chega vindo da escada em caracol, com o Menino. Tem os livros de Maria Thereza Vargas e Maria Inez Barros de Almeida sobre Cacilda e uma frasqueira de figurinos. E restos de anarquistas coroados no exílio dos subterrâneos.

Temos aí uma menção a amigos e companheiros de trabalho de Cacilda Becker, que teriam participado de orações e correntes de pensamento positivo, buscando ajudar a atriz a sair do coma de trinta e nove dias em que penetrou após o derrame cerebral e em que se manteve até sua morte. Mas, se somos remetidos ao ano de 1969, do derrame cerebral, do coma prolongado e da morte da atriz, a menção à Barca da Glória nos conduz ao Auto da Barca do Inferno, de Gil Vicente, e à montagem da peça de que Cacilda participou, sob a direção de Décio de Almeida Prado no Grupo Universitário de Teatro em 1943. 
Esse trecho didascálico mostra o procedimento pelo qual se reúnem, em Cacilda!, a cada momento, imagens díspares, bem como materiais sonoros, linguísticos e imagéticos heterogêneos ou referências verbais e visuais associadas a tempos e contextos distintos, direta ou indiretamente relacionados à vida da protagonista, i. e., a heroína a quem a Jovem Atriz pretende em dado instante fazer um brinde. Em quê exatamente cada um dos elementos imagéticos (vídeos, fotografias, filmes, etc.), sonoros, musicais, verbais e cênico-performáticos - frequentemente múltiplos e simultâneos (cenas na pista e nos mezaninos, atuações de atores e projeções de imagens associadas ou não a eles nos monitores de TV, etc.) - dizem respeito a aspectos biográficos da personagem-título raramente se esclarece por inteiro. Do mesmo modo, não se explicita precisamente qual o elo que se está fazendo em tal ou qual momento com contextos mais amplos (sociais e políticos) em que vivera e atuara a artista morta em 1969. Nunca se estabiliza inteiramente um sentido autocentrado e unificado de época.

Não que seja impossível reconhecer uma série de referências fragmentárias ou parciais a contextos particulares, como nos momentos em que se alude verbalmente ao tenentismo e à Revolução Constitucionalista de 1932, à Segunda Guerra Mundial e à Força Expedicionária Brasileira. Tanto os aspectos de referências históricas e sociais - i. e., não propriamente artísticas e literárias - são suscetíveis de serem apreendidos, quanto as alusões específicas à história do teatro e da literatura dramática podem ser assimiladas a todo instante pelo espectador. Mas o fato é que se verifica a cada momento uma profusão tão intensa de imagens e de informações, fornecidas por canais tão distintos e heterogêneos, sobre contextos igualmente múltiplos e diferenciados, que o efeito produzido é o de uma espécie de deslize de todas as atualidades (a de cada presente, de cada passado e de cada futuro), uma divisão ou dilaceramento de todos os corpos ou identidades, a produção furiosa de uma amálgama deliberadamente esquizofrênica de dados não só incompatíveis entre si, mas resistentes a servirem como elementos de conjunção no interior de composições totalizadoras, como também resistentes ainda à estabilização imaginária de contextos internamente coerentes e de um fluxo temporal unidirecional no imaginário do receptor.

Não é de pouca importância o fato de que os participantes da dança da masturbação usam máscaras como as utilizadas pelos 
atores-bailarinos do Bailado do Deus Morto (1933) de Flávio de Carvalho (1899-1973). O artista e performer avant la lettre já maduro teve um namoro com a jovem Cacilda Becker no final dos anos 30. $\mathrm{O}$ encontro dos dois, assim como o de Cacilda com o amigo Miroel da Silveira, que se torna importante crítico teatral, é encenado no primeiro ato do espetáculo. Mas agora, nós estamos, a princípio, no final dos anos 6o, quando Cacilda já era uma estrela reconhecida. O namoro com Flávio de Carvalho não durou mais de alguns meses e não parece ter tido importância decisiva na vida afetiva de Cacilda. Não há também notícia de uma continuidade da amizade entre ambos. Mas o pequeno aspecto referencial do breve namoro de Cacilda e Flávio de Carvalho levou José Celso a criar associações livres de idéias não só com o Bailado do Deus Morto, mas com a obra de Flávio de Carvalho e suas experiências performáticas, de modo mais amplo, ao longo da peça.

As máscaras de alumínio, concebidas por Flávio para o Bailado, não aparecem apenas na dança erótica dos sátiros masturbadores. Figuram também em inúmeras cenas de coro ao longo do espetáculo. A personagem Flávio de Carvalho, no episódio que trata do namoro com Cacilda, veste um tipo de roupa (que inclui uma pequena saia e blusa meio bufante) que ele usou certa vez nas ruas de São Paulo, em 1956. Vemos também a personagem, representado por Zé Celso, pintando um quadro cujas cores fortes lembram um estilo expressionista de certas pinturas do artista.

É certo, entretanto, que o espectador que não tenha informações prévias sobre o trabalho teatral de Flávio de Carvalho não lerá a cena pelo viés dessa referência artística. Mas penso que não importa, na verdade, que ela seja ou não decodificada. O que importa é que o receptor experimente também ele o jogo paradoxal em que a presença joga com a divisão de si mesma (em termos de profusão de referências díspares, de imagens, vultos, sombras e reflexos) como movimento infinito e sem ponto seguro de chegada.

É curioso verificar que, em Cacilda!, Zé Celso faz também uma grande homenagem a Flávio de Carvalho, artista com quem se pode imaginar que o próprio Zé Celso se identifique infinitamente mais do que com o percurso artístico de Cacilda Becker. Sem dúvida, a cena da masturbação é não apenas uma referência ao espetáculo nova-iorquino Dionysus in 69 do final dos anos 6o, mas também à experiência paulista do Bailado do Deus Morto do início dos anos 30. Muito possivelmente as idéias artísticas de 
Flávio de Carvalho e as informações sobre o Bailado estiveram entre os materiais estudados por Zé Celso para a construção de sua peça. A negação da via estabelecida e racional da arte, o trabalho com o corpo e com certa dimensão de erotismo, bem como a força expressiva ou expressionista do agitador cultural Flávio de Carvalho devem ter causado um forte impacto sobre o dramaturgo-encenador.

Nos espetáculos de Zé Celso realizados nos anos 90, se verifica, por procedimentos diversos, um tipo específico de plasticidade do corpo e do sujeito individual no ambiente polissêmico e plurívoco, fragmentário e múltiplo, em que esse corpo e o sujeito rememorado aparecem. A multiplicidade de canais (vídeos, filmes, jogo de luzes e de sombras, sonorização do espetáculo, etc.) é um dos fatores que contribui para essa plasticização responsável pela disseminação ou divisão de todos os corpos e de todo presente, pela relativa desmaterialização do sentido, isto é, pela desconexão entre o sentido e a concretude particularizadora dos corpos.

Em dado momento do primeiro ato, vemos uma cena longa em que os pais de Cacilda - e depois com a participação das três filhas, ainda meninas, do casal - aparecem não por trás de um tecido como no início da cena dos masturbadores, mas diante de uma cortina de cor clara que funciona, nesse instante, como um pano de fundo. A cena é iluminada pela luz de um projetor de cinema, que está colocado a uma certa distância dos atores. O projetor roda normalmente como se fosse projetar um filme sobre a cortina branca. Ocorre entretanto que não há nenhuma película na máquina. A luz projetada, incidindo sobre os corpos dos atores, produz já não vultos escuros por trás de um tecido, mas sombras sobre o pano de fundo. É como se se indicasse uma problematização da presença cênica por meio da comparação com o cinema, como se fosse operada uma desmaterialização relativa da presença corporal atual dos intérpretes, pelo reflexo, pela duplicação dos corpos. As sombras apontam para uma presença outra, para a presença inatual, não como passado ou futuro, mas como o que não se estabiliza na condição de dado associado a qualquer contexto determinado ou atualidade temporal exclusiva, seja a do presente, a do passado ou a do futuro.

No quadro a que acabo de me referir e que, no texto da peça, recebe o título «Álbum de Família» (referência à peça homônima de Nelson Rodrigues), o Seu Yákonis, pai de Cacilda, diz em certo 
momento: «Parecemos artistas de cinema,/ que fazem, de vez em quando, fitas.» Na parte final da cena, entra, de fato, um filme do Seu Yákonis, pai de Cacilda (representado pelo sempre sorridente e debochado Marcelo Drumond), na cidade de São Paulo. O filme é em preto em branco e lembra a textura de filmes das primeiras décadas do século $\mathrm{xx}^{6}$. Logo depois, haverá uma briga em família, e o Seu Yákonis dirá em cena, antes de ir embora: «[...] acho que vou pra outra fita em série;/ nesta eu ainda acabo mal./ Até um próximo episódio.» A réplica e a cena podem ser associadas à disseminação dos corpos não só em fitas, em imagens, mas também em espaços e tempos múltiplos nos quais se dá a divisão e a multiplicação incessante das coisas e dos indivíduos na peça.

No interior de uma longa rubrica do quadro intitulado «Última Cena», nas primeiras páginas da peça, lê-se a prescrição de «um espelho gigante móvel que rebate a luz em glórias pela pista toda». O longo trecho didascálico, em que se encontra a indicação do espelho a rebater luzes diversas por todas as direções do espaço, dará lugar a uma cena-citação de Esperando Godot, com as personagens Cacilda-Estragon (Bete Coelho) e Walmor-Wladimir (Marcelo Drumond), personagens que amalgamam os protagonistas da peça de Beckett (Estragon e Wladimir) e personagens de Cacilda!, de Zé Celso (Cacilda Becker e Walmor Chagas). Antes dos diálogos extraídos de Esperando Godot, as últimas linhas didascálicas sintetizam a função do quadro:

uma cena pós-pós até do pós-queda, nos anos 80 , do socialismo real e do Wladimir Leninismo. Por isso, desde já, nos subtextos, está todo esse passado-presente. Mas é também uma cena completamente específica, é a última cena, o adeus [...].

É curioso verificar que a cena pretenda remeter tanto ao final dos anos 6o, quando Cacilda Becker estava em cartaz com a peça de Samuel Beckett e sofreu o derrame cerebral em decorrência do qual veio a falecer («última cena», a do adeus), quanto a contextos históricos muito posteriores, como o do fim do regime socialista na Europa do Leste. A idéia do passado-presente que aparece na rubrica (idéia que também se configura como a de passado-futuro) é, na peça 
de Zé Celso, a de um tempo sempre dividido, nunca só presente, nunca inteiramente estável. $O$ rebatimento das luzes por meio do espelho mencionado na rubrica parece colaborar com a divisão dos corpos atuais e com a multiplicação das direções do tempo.

O rebatimento e a mistura de luzes aparecem em outros momentos do espetáculo e do texto da peça. Ainda no início do primeiro ato, há o quadro «Auto das Barcas», quadro que aparece após o derrame de Cacilda, ocorrido no intervalo de uma exibição de Esperando Godot, já ter sido representado. Nesse quadro, se lê, no texto da peça, o seguinte trecho didascálico:

\begin{abstract}
A dama das Camélias vai se maquiando no seu camarote e se carregando no vestir. Enegrece as mãos. Desfigura o rosto com traços exagerados, envelhecendo aos olhos do público, como num butô. Veste uma peruca como as de Ruth Escobar, um cinturão de castidade. Chegam dois barcos no cais do porto de Santos. O BARCO DO TEATRO-VESTIDO DE NOIVA ${ }^{7}$, O INFERNO, tem sirene de ambulância e faróis vermelhos. Faixa imensa: MALDIÇÃo. Base do Teatro Aberto Total de Treplev. Dividido em três planos: 1) Alucinação; 2) Memória; 3) Realidade. A chegada é anunciada pelo porteiro.) (O BARCO DO CÉu é o palco do próprio TCB, somado ao apê da Paulista. Faixa imensa: GLÓRIA. Base do TBC, TCB, do teatro de Arkadina no andar de cima: o Lar - com Deus-Pai (o pai de Cacilda, a compadeCIDA), O Menino-Jesus, Anjos, faróis em azul-celeste).
\end{abstract}

Essa rubrica fala de faróis vermelhos de ambulância (em referência simultânea à Barca do Inferno do auto vicentino e ao derrame de Cacilda, que ocasionou seu transporte para o hospital em uma ambulância, interrompendo a sessão de Esperando Godot), mesclando-se com faróis em azul-celeste (que remetem duplamente à barca do céu da peça de Gil Vicente e à «base do TBC, TCB, do Teatro de Arkadina no andar de cima»). Na mesma rubrica, José Celso reúne, dentre aspectos biográficos diversos, a referência à Barca do Inferno e ao que chama de «O BARCO DO TEATRO-VESTIDO DE NOIVA», que é a «base do Teatro Aberto Total de Treplev» e que é «dividido em três planos: 1) Alucinação; 2) Memória; 3) Realidade».

A mistura de referências teatrais reuniu na mesma rubrica alusões a várias obras dramáticas, como as peças de Gil Vicente (Auto da Barca do Inferno), de Anton Tchékhov (A Gaivota, peça 
de que são personagens, dentre outras, a glamurosa atriz Arkadina, representante do establishment artístico e do mundanismo teatral, seu filho Treplev, o jovem dramaturgo rebelde, assim como Nina, a jovem atriz por quem ele é apaixonado) e de Nelson Rodrigues (Vestido de Noiva). Essa amálgama de referências literárias e teatrais díspares, associadas a contextos histórico-geográficos e culturais muito distintos, se relaciona com a divisão de todo presente, conforme o que vinha comentando. As próprias peças referidas enfatizam a divisão. No texto de Tchékhov, temos a separação do teatro como arte entre as concepções burguesas de Arkadina e as aspirações anárquicas e renovadoras de seu filho Treplev. Nelson Rodrigues dividiu a ação de Vestido de Noiva nos planos da Memória, da Alucinação e da Realidade. A peça de Gil Vicente coloca as personagens, recém-mortas, diante de uma espécie de julgamento de seus atos, julgamento esse que determina que elas embarquem seja na balsa do céu, seja na do inferno.

A divisão nas três peças tem funções distintas, associadas aos temas e aos modos de estruturação de cada uma delas. Gostaria de fazer algumas observações relativas especificamente à utilização que José Celso faz dessas peças, para corroborar meu pensamento de que a divisão joga contra uma concepção de presença e de memória ou história como dado totalmente objetivo, denso e compacto, no modo de estruturação do texto e do espetáculo Cacilda!. Na peça de Tchékhov, a divisão pontua o antagonismo de visões da arte e do mundo entre Treplev e sua mãe Arkadina. Não se trata de um conflito inteiramente cerrado. Há sutilezas e ambiguidades no fluxo dos afetos entre o filho e a mãe. Mas a divisão estrutura a ação dramática e determina sua continuidade dentro de uma temporalidade vetorial ou linear. Aliás, lembre-se que, nessa peça de Tchékhov, se organiza um conflito dramático de modo um pouco mais claro do que em outras do mesmo autor, a exemplo de $O$ Jardim das Cerejeiras e de As Três Irmãs, peças nas quais a capacidade das personagens de agirem e de se oporem aos obstáculos antepostos por possíveis adversários - definindo assim um âmbito de conflito interpessoal - parece decididamente mais diluída do que em A Gaivota, apesar de o suicídio de Treplev também indicar sua fragilidade como personagem dramática.

No caso da peça quinhentista de autoria de Gil Vicente, a divisão tem a ver com uma alternativa entre duas possibilidades de encaminhamento das personagens após a morte. As duas 
barcas têm seus líderes, o Anjo e o Diabo. As embarcações que eles comandam constituem espaços semânticos claros e não intercambiáveis. O tempo na peça implica uma espécie de repetição do mesmo tipo de situação: o impasse dos recém-mortos ante as duas barcas e o julgamento prévio ao qual não podem fugir antes de embarcarem em uma delas. Esse módulo situacional retorna a cada personagem que entra em cena.

Na peça de Nelson Rodrigues, os três planos (memória, realidade, alucinação) já não são tão rigidamente definidos quanto os espaços das duas barcas e os valores que elas representam no auto vicentino. Os aspectos relativos à memória e à realidade, em Vestido de Noiva, parecem contaminados pela alucinação e pelo delírio da personagem Alaíde, hospitalizada de emergência em decorrência do atropelamento de carro que sofrera. Mas as cenas da peça-que se estrutura como uma espécie teatral de fluxo de consciência de Alaíde - têm todas uma certa coerência com as vivências efetivas da protagonista: o modo como ela experimentou no passado as suas relações familiares, o seu casamento, a descoberta do diário de uma prostituta (Madame Cléssy) morta muitos anos antes, diário esse que fora encontrado por Alaíde, quando ainda muito jovem, na casa de seus pais. De algum modo, podemos dizer que as misturas de tempo e as interpenetrações entre memórias de fatos efetivamente vividos e delírios que levam a personagem a fantasiar e mesclar o factual e o imaginário estão todas reunidas em certo campo psicológico ou subjetivo restrito, qual seja o âmbito dos afetos e da vida psíquica de Alaíde, que se encontra sob o efeito do trauma do acidente.

Na peça de Zé Celso, também há a encenação de uma espécie de fluxo de memórias e de delírios de uma personagem em situação patológica ou traumática, decorrente agora não de um atropelamento, porém de um derrame cerebral. Mas em Cacilda!, não há o fechamento do foco no campo das possíveis vivências efetivas ou imaginárias da personagem. O movimento delirante da alucinação e das mesclas, da divisão de todos os corpos e todos os tempos pela interpenetração de elementos estranhos a cada um deles, é em Cacilda! mais cego do que em Vestido de Noiva aos possíveis contornos delimitadores de um campo geral de coerência e de justificação central ou centrada das ocorrências, misturas e divisões.

A proliferação de referências literárias e biográficas em Cacilda! está ligada a uma potência violenta de movimentação de forças que 
destituem, em todo presente e em todo corpo, a possibilidade de fechamento, de individuação e de identidade de cada um consigo próprio. Não se trata de mera oposição entre imaginário e real. A diferença nunca é apenas a de cada coisa em relação à outra da qual ela se distingue. Mas também não se trata da perda de fronteiras sustentada por certos elos causais. Há o derrame cerebral que justifica o coma e os possíveis delírios da personagem. Mas o que se processa como mesclas, divisões, digressões narrativas e disseminações do referente ficcional, ao longo da peça, rompe e ultrapassa os limites de um campo de justificativa e de causalidade razoavelmente delimitado.

Em Cacilda!, estamos diante da divisão como diferença de cada coisa e de cada um consigo mesmo, como proliferação infinita, que nem mesmo se limita ao arco do que é suscetível de ser imaginado ou fantasiado a partir de estímulos provenientes de vivências efetivas de uma personagem. A divisão, na peça, não se prende também ao que pode se justificar a partir de um contexto social, de uma realidade familiar ou de um horizonte histórico em que se inserisse a personagem na qual se poderia localizar o foco narrativo.

Há um aspecto que chama também a atenção quando se trata de tentar entender as questões da presença e de sua relação com o corpo, a memória e a realidade, em Cacilda!. Refiro-me às várias cenas em que o corpo, líquido e mole, parece ser apenas sangue e fluxo, continente de fluidos. Quando Cacilda, já fora de sentidos, está na UTI do hospital para o qual foi encaminhada, os médicos lembram aqueles outros que, em Vestido de Noiva, fazem uma intervenção cirúrgica em Alaíde. Em dado momento da cena, o coro dos médicos pronuncia a seguinte réplica:

\footnotetext{
Aneurisma/Roto cerebral/ Aí está:/ é como pau entumescendo/ uma bolsa de sangue/ irrompendo as artérias/ do cérebro./ Vamos abrir vias,/ deixar sangrar.
}

Pouco depois, vemos a drenagem cerebral. A UTI se localiza na varanda superior em que, noutro momento, se dão as cenas da masturbação e do apartamento de Cacilda na avenida Paulista. A rubrica desse momento da operação, que ocorre no quadro intitulado «A Mídia», descreve a ação do seguinte modo: 
A drenagem é feita. O Brasil que não foi possível se esvai. Nos vídeos, uma explosão silenciosa de uma Hiroshima na cabeça dos anos 60 - lavagem cerebral, ipsis litteris, o sangue jorra de toda a explosão contida de 68 , em gotas vermelhas, no centro da pista. Os monitores de vídeo acusam um gol de futebol, interrompido no silêncio da parada cardíaca. Os pingos começam a aumentar, esvaindo de dentro dela e jorrando em lava vermelha na pista.

A solução cênica efetiva, de grande impacto visual, incluiu outros elementos. A cirurgia foi feita com a utilização de uma máquina elétrica de furar e de um crânio de adereço, que era efetivamente perfurado em cena. Depois, descia do mezanino-hospital um enorme plástico, que vinha dar em meio ao palco-pista. As duas extremidades do imenso plástico eram seguras por atores na varanda superior e no palco. A seguir, entornava-se lá do alto um balde de água tingida de vermelho. O líquido escorria pelo plástico transparente e desembocava no balde embaixo.

Outra cena que diz respeito a sangue aparece no quadro intitulado «Menstruação». Nele, a primeira menstruação da jovem Cacilda é representada por um enorme fio de corda vermelha. Inicialmente, vemos a protagonista ter um desmaio e cair. Depois, uma das irmãs de Cacilda desenrola um fio que sai de dentro das pernas da que desmaiara. Fio esse que se estende ao longo de quase toda a extensão do palco-pista.

Ao lado das menções a sangue, há também muitas referências à chuva, à água e ao mar. $\mathrm{O}$ mar de Santos é representado com a utilização de enormes faixas de tecido. Em dado momento, na parte inicial da peça, a menina Cacilda (Bete Coelho) brinca sob chuva. Já no trecho final, no quadro «Confissão», Treplev diz à Cacilda-Arkadina:

[...] Agora vou decapitar você, minha mãe!/ Arkadina! Cacilda!/ Entrei em coma com você! Mas como esse coma/ E nestas chuvas renasço.

Um pouco depois, no quadro intitulado «Comunhão da Laranja Dourada-Hóstia do Teatro», Cacilda-Maria (referência à personagem da peça Mary Stuart, de Schiller, representada por Cacilda Becker em 1955 e 1958) diz: 
ternura/ das fraquezas demasiadamente humanas,/ agora/ são soberanas./ Sinto de novo a coroa,/ porque meu coração está mole/ líquido e banha minha cabeça./ Cheguei no limiar da eternidade./Dentro de alguns minutos/ serei chão, serei chuva.../ Diretora das Diretoras,/ choverei nas hortas,/ nas terras dos palcos,/ pondo visível/ céu, terra e inferno, na presença do corpo/da atriz.

O coração se amolece, se liquefaz e o sujeito se torna chuva, pulveriza-se, dissemina-se. A «presença do corpo da atriz» é ponto de junção de partes e de indeterminação das mesmas. Não se trata de uma presença dividida entre outras que não o são. Trata-se da presença que só se constitui como tal porque dividida e/ou multiplicada, porque disseminada não só em «céu, terra e inferno», mas também nos corpos de muitas atrizes, em outras presenças, por sua vez, também divididas e disseminadas. A menina Cacilda aparece predominantemente no corpo da atriz Bete Coelho, ainda que a mesma intérprete represente também a Cacilda-Estragon e a Cacilda-Pega Fogo (ambas sendo referências a personagens interpretadas por Cacilda Becker na maturidade). Leona Cavalli também dá corpo a várias Cacildas: Cacilda-Dama das Camélias da Morta, Cacilda-Arkadina, Cacilda-Margarida Gautier e Cacilda-Mary Stuart, dentre outras. Essas últimas Cacildas incluem referências a peças que a estrela efetivamente representou em sua carreira e a outras em que nunca atuou, como é o caso de A Morta, de Oswald de Andrade, e A Gaivota, conforme o que já comentei anteriormente.

Mas há outras disseminações do «corpo da atriz». Lígia Cortez, que é responsável pela personagem de Dona Alzira, mãe de Cacilda Becker, é também Cacilda-Brízida Vaz (a cafetina do Auto da Barca do Inferno) e Cacilda-Kitti Duval (prostituta que figura na peça Nick Bar... Álcool, Brinquedos, Ambições, de William Saroyan). Quando Cacilda-Estragon (Bete Coelho) desmaia no primeiro ato, a Cacilda disseminada em Leona Cavalli também desfalece em eco. No quadro «Menstruação», a Cacilda-Kitty Duval (Lígia Cortez) aparece para a moça Cacilda Becker (Bete Coelho) fazendo uma espécie de ritual de iniciação da menina na vida de mulher, dando-lhe um batom e um espelho. Fluxos, água, líquidos junto ao fornecimento intenso de informações e referências díspares, a todo instante e por meios diversos (vídeos, projeção de fotografias, música, etc.) constituem alguns dos materiais e procedimentos 
formais para a operação particular de extrapolação de limites tanto espaciais quanto temporais na peça. Operação essa por meio da qual se definem, no espetáculo, o tipo de relação com o tempo, a memória individual e a história coletiva, que Zé Celso tende a trabalhar, não apenas nesse projeto, mas, de forma ampla e diferenciada, no conjunto de suas realizações teatrais no Teatro Oficina.

\section{REFERÊNCIAS BIBLIOGRÁFICAS}

O SóR IO, Luiz Camillo (200o), Flávio de Carvalho, [São Paulo], Cosac \& Naify.

PRADO, Luís André (2002), Cacilda Becker: Fúria santa, São Paulo, Geração Editorial.

O PERCEVEJO: REVISTA DE TEATRO, CRÍTICA E ESTÉTICA (1997), ano 5, n. ${ }^{\circ} 5$ - Dossiê Modernistas no Teatro Brasileiro II, Departamento de Teoria do Teatro e Programa de Pós-Graduação em Teatro da Universidade do Rio de Janeiro (UNIRIO). 